\title{
Potential Development of a Mobile Application for Gout Self-Management: What Support Do Patients Need? [Corrigendum]
}

\author{
Yin Y, Wang H, Fan CF, Chen H. Patient Prefer \\ Adherence. 2021;15:2231-2238.
}

The authors have advised affiliation 1 on page 2231 is incorrect. The text "Department of Neurology/Evidence- based Nursing Center" should read "Department of Neurological Comprehensive Ward/Evidence-based Nursing Center".

The authors apologize for this error.

\section{Publish your work in this journal}

Patient Preference and Adherence is an international, peer-reviewed, open access journal that focusing on the growing importance of patient preference and adherence throughout the therapeutic continuum. Patient satisfaction, acceptability, quality of life, compliance, persistence and their role in developing new therapeutic modalities and compounds to optimize clinical outcomes for existing disease states are major areas of interest for the journal. This journal has been accepted for indexing on PubMed Central. The manuscript management system is completely online and includes a very quick and fair peer-review system, which is all easy to use. Visit http:// www.dovepress.com/testimonials.php to read real quotes from published authors. 